\title{
Capsaicin Inhibits the Spontaneous Pacemaker Activity in Interstitial Cells of Cajal From the Small Intestine of Mouse
}

Seok Choi, PhD, Jae Myeong Sun, MD, Pawan Kumar Shahi, PhD, Dong Chuan Zuo, PhD, Hyun II Kim, MD and Jae Yeoul Jun, MD*

Department of Physiology, College of Medicine, Chosun University, Gwangiu, Korea

\section{Background/Aims}

Capsaicin (8-methyl-N-vanillyl-6-ninenamide), a compound found in hot peppers, has been reported to have different physiological actions on different cell types. Not much work has been done about the effect of capsaicin on the function of interstitial cells of Cajal (ICC). In the present study, we examined the action of external application of capsaicin on pacemaker activity in the cultured ICC from the small intestine of mouse.

\section{Methods}

We investigated the effect of capsaicin on pacemaker currents in cultured ICC from the small intestine of mouse using a whole cell patch-clamp technique and $\mathrm{Ca}^{2+}$-imaging analysis.

\section{Results}

When capsaicin was applied externally to the pacemaker generating ICC, it completely inhibited the pacemaker potential under current-clamp mode $(I=0)$ and the pacemaker current under voltage-clamp mode at a $-70 \mathrm{mV}$ of holding potentials. The effect of capsaicin on pacemaker activity in ICC was shown dose dependently. The effect of capsaicin was not through the transient receptor potential of the vanilloid type 1 (TRPV1) channel as capsazepine did not block the effect of capsaicin. L-NAME, an inhibitor of nitric oxide synthase, also did not block the capsaicin-induced effects. When the action of capsaicin was examined in the intracellular calcium oscillation, it completely abolished the calcium oscillation.

\section{Conclusions}

These results prove that the capsaicin has the inhibitory effects on the ICC which is carried out neither through TRPV channel nor the nitric oxide production. Intracellular $\mathrm{Ca}^{2+}$ was also an important target for actions of capsaicin on ICC.

(J Neurogastroenterol Motil 2010;16:265-273)

\section{Key Words}

Capsaicin, Interstitial cells of Cajal, Pacemaker current, Gastrointestinal motility

Received: March 4, 2010 Revised: April 22, 2010 Accepted: April 28, 2010

(c) This is an Open Access article distributed under the terms of the Creative Commons Attribution Non-Commercial License (http://creativecommons. org/licenses/by-nc/3.0) which permits unrestricted non-commercial use, distribution, and reproduction in any medium, provided the original work is properly cited.

*Correspondence: Jae Yeoul Jun, MD

Department of Physiology, College of Medicine, Chosun University, 375 Seosuk-dong, Gwangju 501-759, Korea

Tel: +82-62-230-6412, Fax: +82-62-232-4943, E-mail: jyjun@chosun.ac.kr

Financial support: This work was supported by Chosun University in 2009.

Conflicts of interest: None. 


\section{Introduction}

Capsaicin (8-methyl- $N$-vanillyl-6-ninenamide) is a compound which is available in a various types of hot peppers and is famous for its pungent taste, burning sensation, and various effects on body temperature and gastric acid secretion. Because of its analgesic and anti-inflammatory activities, topical application of capsaicin has been used in clinical practice for the treatment of a variety of neuropathic pain conditions. ${ }^{1}$ The characteristic effects of capsaicin are known to be mediated by stimulating the polymodal vanilloid receptors of type 1 , also termed as transient receptor potential of the vanilloid type $1(\mathrm{TRPV} 1)^{2}$ and it is well known that capsaicin is a selective stimulant for mammalian afferent neurons of dorsal root ganglia with $\mathrm{C}$ and $\mathrm{A}$ thin fibers, which in large doses produce desensitization to the drug itself and to other stimuli of sensory neurons. ${ }^{3,4}$ Capsaicin is also involved in the subsequent release of several neuroregulatory peptides, including substance $\mathrm{P}$ and calcitonin-gene related peptide, from the nerve terminals of thin afferent fibers. ${ }^{5,6}$

Capsaicin, as demonstrated in many reports, exerts many biological activities on different cells. It has been found to act on the capsaicin-sensitive afferent nerves and has been extensively studied in vivo and in vitro for the treatment of migraine, chronic cough, overactive bladder and diabetes, ${ }^{7,8}$ and also as a potent analgesic ${ }^{9}$ and anti-cancer agent. ${ }^{10}$ Interestingly, many studies have demonstrated capsaicin to have effects on gastrointestinal (GI) motility. For example, capsaicin induces contractions in the guinea-pig's ileum ${ }^{11}$ and relaxations in human small and large intestines. $^{12-14}$

Interstitial cells of Cajal (ICC) are the pacemaking cells in the GI muscles which generate the rhythmic oscillations in the membrane potential known as slow waves. Auto-rhythmicity in the GI muscles is an exclusive property of ICC and the spread of slow waves through the GI muscles occurs electrically, rather than by active regeneration. Pacemaking ICC are organized into electrically coupled networks within discrete areas of the stomach, small bowel, and colon. ${ }^{15-19}$

It has been established that capsaicin activates afferent fiber endings and capsaicin-sensitive primary afferent neurons participate in the regulation of GI motility. ${ }^{12-14}$ However, there are no reports on the effect of capsaicin on ICC which plays important roles for the regulation of GI motility. In the present study, we tried to examine the role of capsaicin on ICC in the small intestine of mouse.

\section{Materials and Methods}

All experiments were performed according to the Guiding Principles for the Care and Use of Animals approved by the Ethics Committee of Chosun University and the National Institutes of Health Guide for the Care and Use of Laboratory Animals. Every effort was made to minimize both the number of animals used and their suffering.

\section{Preparation of cells}

Balb/C mice (8-13 day old) of either sex were anesthetized with diethyl ether and killed by cervical dislocation. The small intestines from $1 \mathrm{~cm}$ below the pyloric ring to the cecum were removed and were opened along the mesenteric border. The luminal contents were washed away with Krebs-Ringer bicarbonate solution. The tissues were pinned to the base of a Sylgard dish and the mucosa was removed by sharp dissection. Small strips of intestinal muscle were equilibrated in $\mathrm{Ca}^{2+}$-free Hank's solution containing $\mathrm{KCl} 5.36 \mathrm{mM}, \mathrm{NaCl} 125 \mathrm{mM}, \mathrm{NaOH} 0.336 \mathrm{mM}$, $\mathrm{Na}_{2} \mathrm{HCO}_{3} 0.44 \mathrm{mM}$, glucose $10 \mathrm{mM}$, sucrose $2.9 \mathrm{mM}$, and HEPES $11 \mathrm{mM}$, adjusted to $\mathrm{pH} 7.4$ with Tris for 30 minutes. After incubation for 15 minutes at $37^{\circ} \mathrm{C}$ with an enzyme solution containing collagenase $1.3 \mathrm{mg} / \mathrm{mL}$ (Worthington Biochemical, Lakewood, NJ, USA), bovine serum albumin $2 \mathrm{mg} / \mathrm{mL}$ (Sigma, St. Louis, MO, USA), trypsin inhibitor $2 \mathrm{mg} / \mathrm{mL}$ (Sigma), and ATP $0.27 \mathrm{mg} / \mathrm{mL}$, the cells were dispersed. Cells were plated onto sterile glass coverslips coated with Poly-L-lysine solution (Sigma) in $35 \mathrm{~mm}$ culture dishes. ${ }^{20}$ The cells were then cultured at $37^{\circ} \mathrm{C}$ in a $5 \% \mathrm{CO}_{2}$ incubator in smooth muscle growth medium (Lonza, Cambrex Bio SciencesWalkersville Inc., Walkersville, MD, USA) supplemented with $2 \%$ antibiotics/antimycotics (Gibco, Grand Island, NY, USA) and murine stem cell factor 5 $\mathrm{ng} / \mathrm{mL}$ (SCF, Sigma).

\section{Patch-clamp experiments}

The patch-clamp experiments of ICC were performed on cells cultured for 2-3 days. The whole-cell configuration of the patch-clamp technique was used to record the membrane currents (voltage clamp) and membrane potentials (current clamp) from cultured ICC. Currents or potentials were amplified using Axopatch 1-D (Axon Instruments, Foster City, CA, USA). Command pulse was applied using an IBM-compatible personal computer and pClamp software (version 9.2, Axon Instruments). The data were filtered at $5 \mathrm{KHz}$. All experiments were carried 
out at $30^{\circ} \mathrm{C}$. The results were analyzed using pClamp and Graph Pad Prism (version 2.01, GraphPad Software Inc, San Diego, CA, USA) software.

\section{Measurement of the intracellular $\mathrm{Ca}^{2+}$ concentration}

Changes in the intracellular $\mathrm{Ca}^{2+}$ concentration $\left(\left[\mathrm{Ca}^{2+}\right]_{\mathrm{i}}\right)$ were monitored by using fluo-4/AM, which was initially dissolved in dimethyl sulfoxide and stored at $-20^{\circ} \mathrm{C}$. The cultured ICC on coverslips $(25 \mathrm{~mm})$ were rinsed twice with a bath solution. The coverslips were then incubated in the bath solution containing $5 \mathrm{M}$ fluo- 4 with $5 \% \mathrm{CO}_{2}$ at $37^{\circ} \mathrm{C}$ for 5 minutes, rinsed 2 more times with the bath solution, mounted on a perfusion chamber, and scanned every 0.4 seconds with Nikon Eclipse TE200 inverted microscope equipped with a Perkin-Elmer Ultraview Confocal Scanner and a Hamamatsu Orca ER 12-bit CCD camera (×200; Hamamatsu Instrument, Hamamatsu, Shizuoka, Japan). Fluorescence was excited at a wavelength of $488 \mathrm{~nm}$, and emitted light was observed at $515 \mathrm{~nm}$. During scanning of the $\mathrm{Ca}^{2+}$ imaging, the temperature of the perfusion chamber containing the cultured ICC was kept at $30^{\circ} \mathrm{C}$. The variations of $\left[\mathrm{Ca}^{2+}\right]_{\mathrm{i}}$ fluorescence emission intensity were expressed as $\mathrm{F} 1 / \mathrm{F} 0$ where $\mathrm{F} 0$ is the intensity of the first imaging.

\section{Solutions and drugs}

The cells were bathed in a standard solution containing $\mathrm{KCl}$ $5 \mathrm{mM}, \mathrm{NaCl} 135 \mathrm{mM}, \mathrm{CaCl}_{2} 2 \mathrm{mM}$, glucose $10 \mathrm{mM}, \mathrm{MgCl}_{2}$ $1.2 \mathrm{mM}$, and HEPES $10 \mathrm{mM}$ adjusted to $\mathrm{pH} 7.4$ with Tris. The pipette solution contained K-aspartate $120 \mathrm{mM}, \mathrm{KCl} 20$ $\mathrm{mM}, \mathrm{MgCl}_{2} 5 \mathrm{mM}, \mathrm{K}_{2} \mathrm{ATP} 2.7 \mathrm{mM}, \mathrm{Na}_{2} \mathrm{GTP} 0.1 \mathrm{mM}$, creatine phosphate disodium $2.5 \mathrm{mM}$, EGTA $0.1 \mathrm{mM}$, and HEPES $5 \mathrm{mM}$, adjusted to $\mathrm{pH} 7.4$ with Tris.

The drugs used were: capsaicin, capsazepine, L-NAME and fluo-4. All drugs were purchased from Sigma except fluo-4 (Invitrogen, Eugene, Oregon, USA).

\section{Statistical methods}

Data are expressed as the mean \pm standard errors. Differences in the data were evaluated using Student's $t$ test. A p-value of less than 0.05 was taken as a statistically significant difference. The $\mathrm{n}$ values reported in the text refer to the number of cells used in the patch-clamp experiments.

A

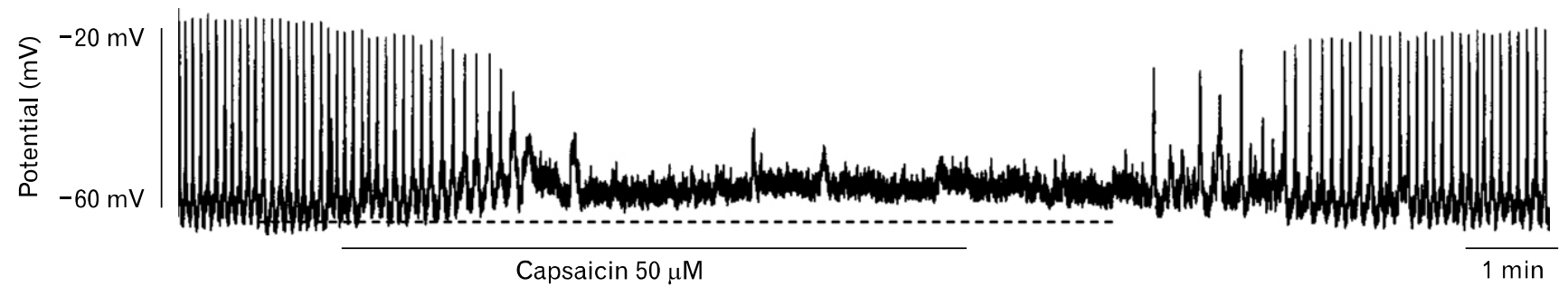

B

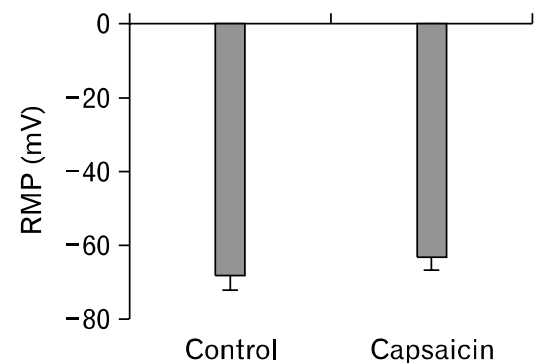

C

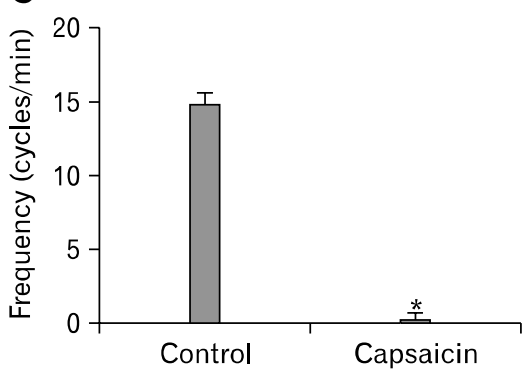

D

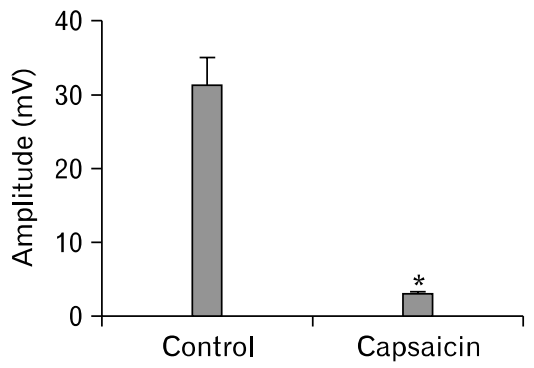

Figure 1. Effects of capsaicin on pacemaker potentials in cultured interstitial cells of Cajal (ICC) from the small intestine of mouse. (A) Pacemaker potentials of ICC exposed to capsaicin $(50 \mu \mathrm{M})$ in the current clamping mode $(I=0)$. The dot lines indicate the control resting membrane potentials levels. It shows the capsaicin effect on resting membrane potential (B), frequency (C) and amplitude (D) respectively at the current clamp mode $(I=0)$. The horizontal solid line scales duration of time. *Significantly different from the untreated Control $(\mathrm{p}<0.05)$. RMP, resting membrane potential. The bars represent mean values $\pm \mathrm{SE}$. 


\section{Results}

1. Effects of capsaicin on membrane potentials and pacemaker currents in ICC

The effect of capsaicin on the cultured ICC was evaluated in both the current and voltage clamp. Spontaneous pacemaker potentials were generated when recordings were done on the cultured ICC in current clamp mode $(I=0)$. Under the current

A

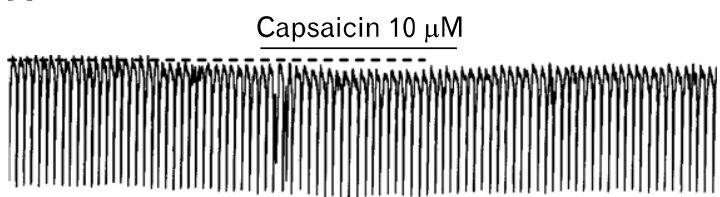

B

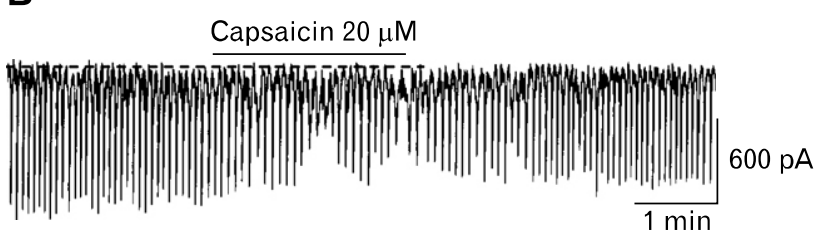

C

\section{Capsaicin $50 \mu \mathrm{M}$}

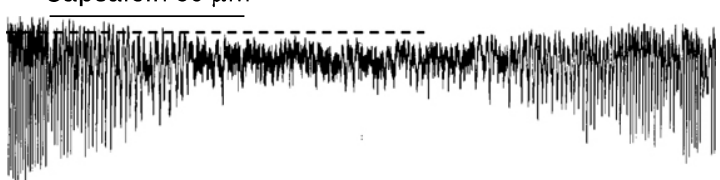

clamp condition, capsaicin $(50 \mu \mathrm{M})$ inhibited the spontaneous pacemaker potentials (Fig. 1A). The resting membrane potential, frequency and the amplitude of ICC without capsaicin were -68.2 $\pm 3.1 \mathrm{mV}, 14.7 \pm 1.6 \mathrm{cycles} / \mathrm{min}$ and $31.0 \pm 3.3 \mathrm{mV}$ respectively. After the treatment of capsaicin $(50 \mu \mathrm{M})$, the resting membrane potential slightly depolarized to $-64.1 \pm 3.4 \mathrm{mV}$ and the frequency and amplitude decreased to $0.9 \pm 0.2 \mathrm{cycles} / \mathrm{min}$ and $3.0 \pm 0.5 \mathrm{mV}(\mathrm{n}=5$, Fig. 1B-D $)$.
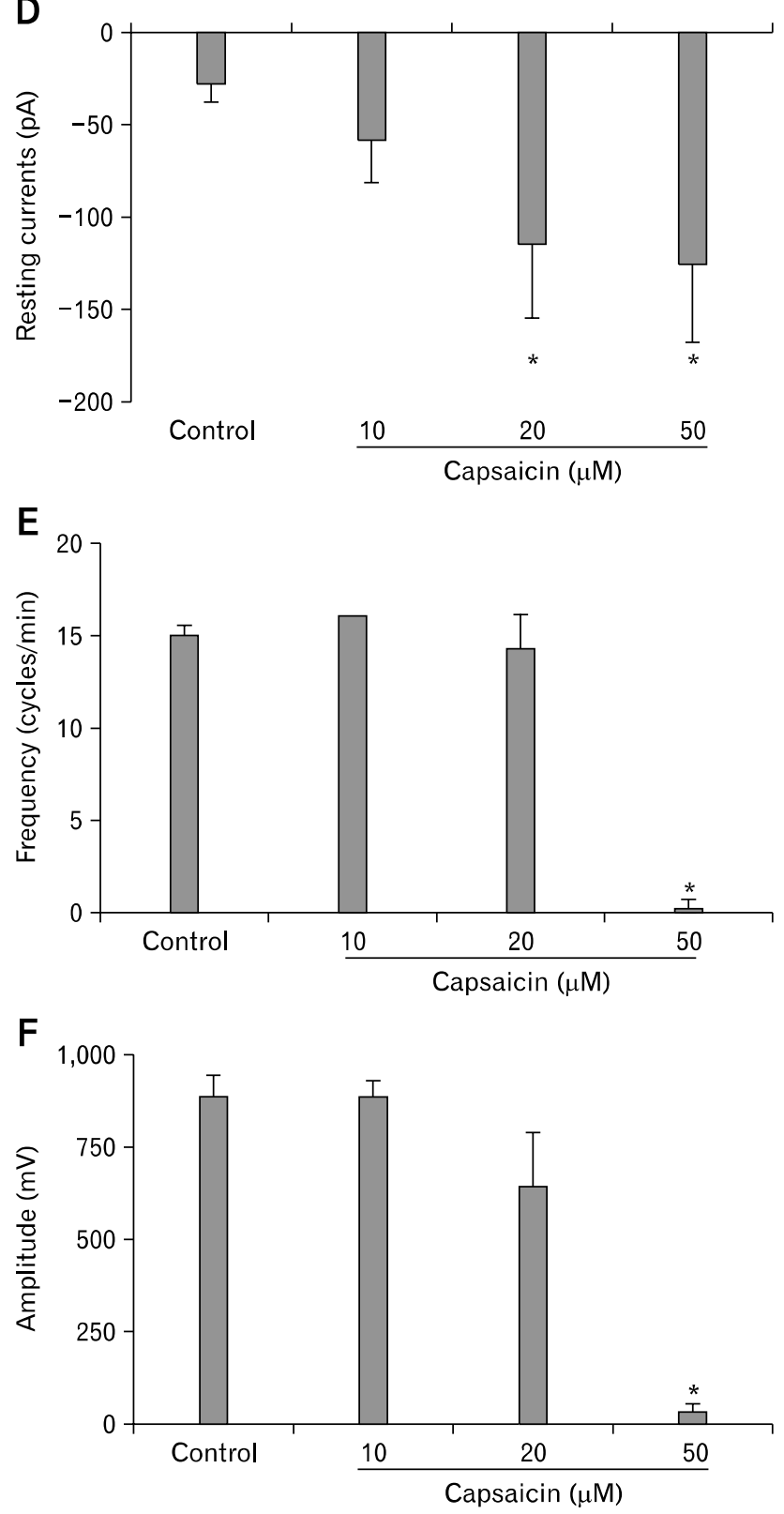

Figure 2. The dose-dependence of capsaicin on pacemaker currents in cultured interstitial cells of Cajal from the small intestine of mouse. There is the effect of capsaicin on pacemaker current at the concentration of 10 $\mu \mathrm{M}, 20 \mu \mathrm{M}$, and $50 \mu \mathrm{M}$ respectively at a holding potential of $-70 \mathrm{mV}$ (A-C). The dot lines indicate the control resting current levels. It shows the inhibitory action (D-F). *Significantly different from the untreated Control $(\mathrm{p}<0.05)$. The bars represent mean values $\pm \mathrm{SE}$. 
A
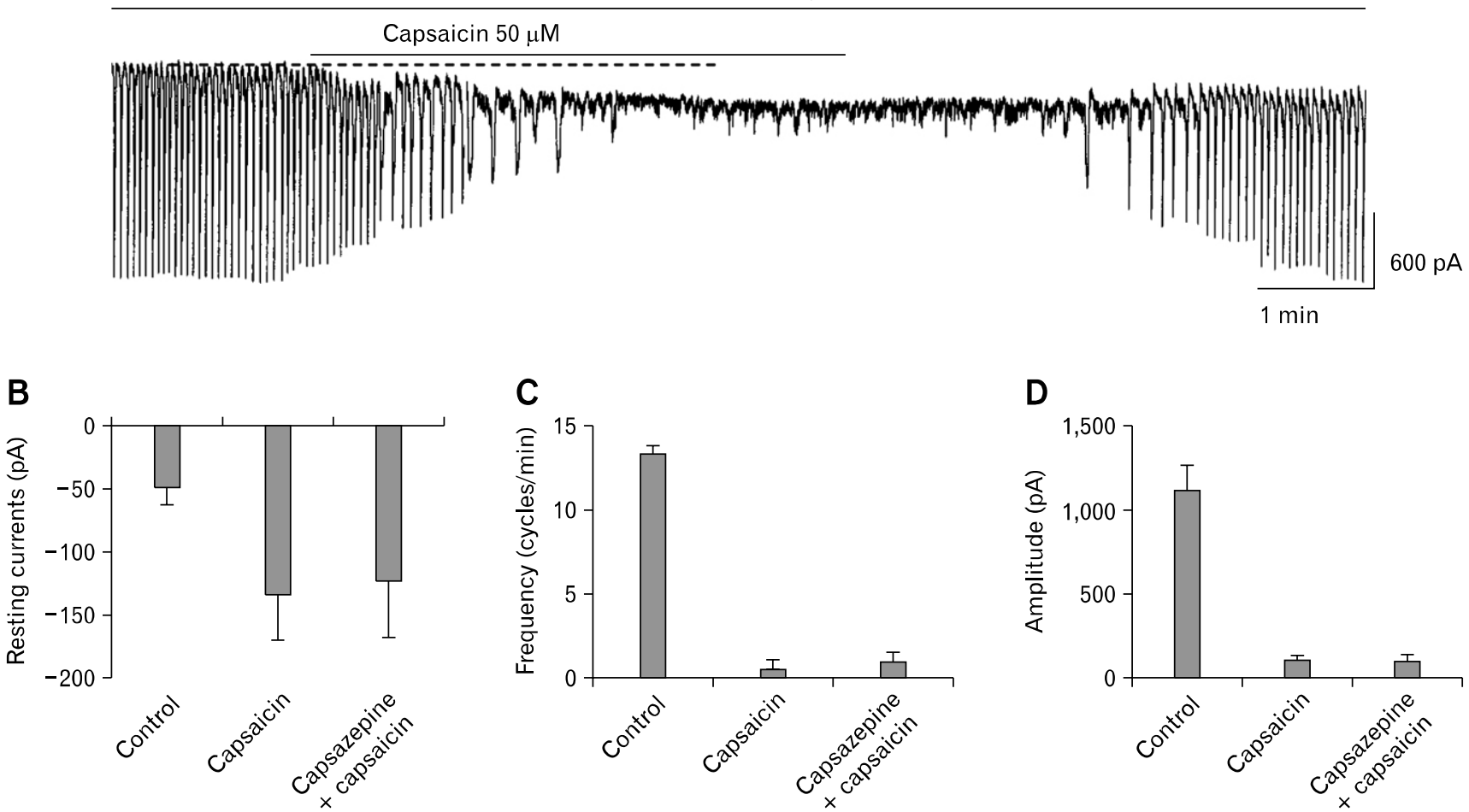

Figure 3. Effect of capsaicin in the presence of transient receptor potential of the vanilloid type 1 receptor antagonist, capsazepine on pacemaker currents in cultured interstitial cells of Cajal. (A) Capsaicin $(50 \mu \mathrm{M})$ showing the inhibitory action with the presence of capsazepine $(10 \mu \mathrm{M})$. The dot lines indicate the control resting current levels. It shows capsaicin's inhibitory effect in the presence of capsazepine (B-D). The bars represent mean values $\pm \mathrm{SE}$.

\section{Dose dependent effect of capsaicin on ICC pacemaker currents}

Under the voltage clamp mode at a holding potential of -70 $\mathrm{mV}$, different concentrations of capsaicin were applied on the cultured ICC to check if the effects were in dose dependent manner. Spontaneous inward currents also known as "pacemaker currents" were generated by ICC when the amplifier was converted to voltage clamp mode at a holding potential of $-70 \mathrm{mV}$. Since many reports have used 1 to $100 \mu \mathrm{M}$ of capsaicin in cellular lev$\mathrm{el}^{21,22}$ firstly we tested $10 \mu \mathrm{M}$ of capsaicin. But $10 \mu \mathrm{M}$ capsaicin could not show any influence on pacemaker current of ICC ( $\mathrm{n}=$ 7, Fig. 2A). When the concentration was increased to $20 \mu \mathrm{M}$, a little decrement in the frequency and amplitude was noticed ( $\mathrm{n}=$ 9, Fig. 2B). With the concentration of capsaicin further increased up to $50 \mu \mathrm{M}(\mathrm{n}=11$, Fig. $2 \mathrm{C})$, the pacemaker current was completely attenuated and the resting current was slightly changed to an inward direction but when compared to the control it was negligible. In the presence of capsaicin, the corresponding values of resting current, frequency and amplitude are shown in Figure $2 \mathrm{D}, \mathrm{E}$ and $\mathrm{F}$ and the values at $50 \mu \mathrm{M}$ were significantly different from control values.

\section{No involvement of TRPV1 receptor on capsaicin-in- duced action and the effects of reduced external $\mathrm{Na}^{+}$ on pacemaker activity in ICC}

Many experiments on different cells reported capsaicin to show effects on those cells through the TRP vanilloid receptor type1. As we could see the effect of capsaicin on ICC, we needed to know if this effect was through the TRPV1 channel. We incubated the ICC with the TRPV1 receptor antagonist capsazepine at a concentration of $10 \mu \mathrm{M}$ prior to the treatment of capsaicin. The inhibitory effect of capsaicin $(50 \mu \mathrm{M})$ was not blocked even with the pretreatment of TRPV1 antagonist in the voltage clamp mode at a holding potential of $-70 \mathrm{mV}$ (Fig. 3A). The frequency, amplitude, and the resting current before and after the treatment of capsazepine with co-treatment of capsaicin were $0.37 \pm 0.37$ cycles $/ \mathrm{min}, 94.98 \pm 24.40 \mathrm{pA}$, and $-132.3 \pm$ 
$35.97 \mathrm{pA}$ and $0.85 \pm 0.59$ cycles/min, $94.85 \pm 28.54 \mathrm{pA}$, and $-124.0 \pm 42.05 \mathrm{pA}$ respectively $(\mathrm{n}=7$, Fig. $3 \mathrm{~B}-\mathrm{D})$. The above data indicate that there were no significant differences in the values between capsaicin alone and with capsazepine.

\section{No involvement of nitric oxide on capsaicin-induced action}

The effects of L-NAME were examined to investigate the possible regulation of pacemaker currents by capsaicin. L-NAME $(10 \mu \mathrm{M})$ was pretreated for 10 minutes before application of capsaicin $(50 \mu \mathrm{M})$. The inhibitory effect of capsaicin was not blocked even with pretreatment of L-NAME in the voltage clamp mode at a holding potential of $-70 \mathrm{mV}$ (Fig. 4A). In the presence of L-NAME, the resting currents by capsaicin was $-116.6 \pm 32 \mathrm{pA}$, and the frequency and amplitude of the pacemaker currents were $0.58 \pm 2.7$ cycles $/ \mathrm{min}$ and $69.4 \pm 32.6 \mathrm{pA}$, respectively ( $\mathrm{n}=4$, Fig. 4B-D). L-NAME itself had no effect on pacemaker currents.

\section{Effect of capsaicin in the intracellular calcium oscillation}

As many reports suggested that $\left[\mathrm{Ca}^{2+}\right]_{\mathrm{i}}$ oscillations in ICC were considered to be the primary mechanism for the pacemaker activity in gastrointestinal activity, we examined the effects of capsaicin on $\left[\mathrm{Ca}^{2+}\right]_{\mathrm{i}}$ oscillations in ICC. In this study, we measured the spontaneous $\left[\mathrm{Ca}^{2+}\right]_{\mathrm{i}}$ oscillations of ICC which were connected with cell clusters. Spontaneous $\left[\mathrm{Ca}^{2+}\right]_{\mathrm{i}}$ oscillations were observed in many ICC loaded with fluo-4. Figure $5 \mathrm{~A}$ shows images of basal ( $\mathrm{F} 0)$ and peak point $(\mathrm{F} 1 / \mathrm{F} 0)$ of $\mathrm{Ca}^{2+}$ oscillations. In the presence of $50 \mu \mathrm{M}$ capsaicin, $\left[\mathrm{Ca}^{2+}\right]_{\mathrm{i}}$ oscillations in ICC declined rapidly (Fig. 5B). The data of time series are summarized in Figure $5 \mathrm{C}$.

\section{Discussion}

In the present study, we have shown the capsaicin to have in-

A
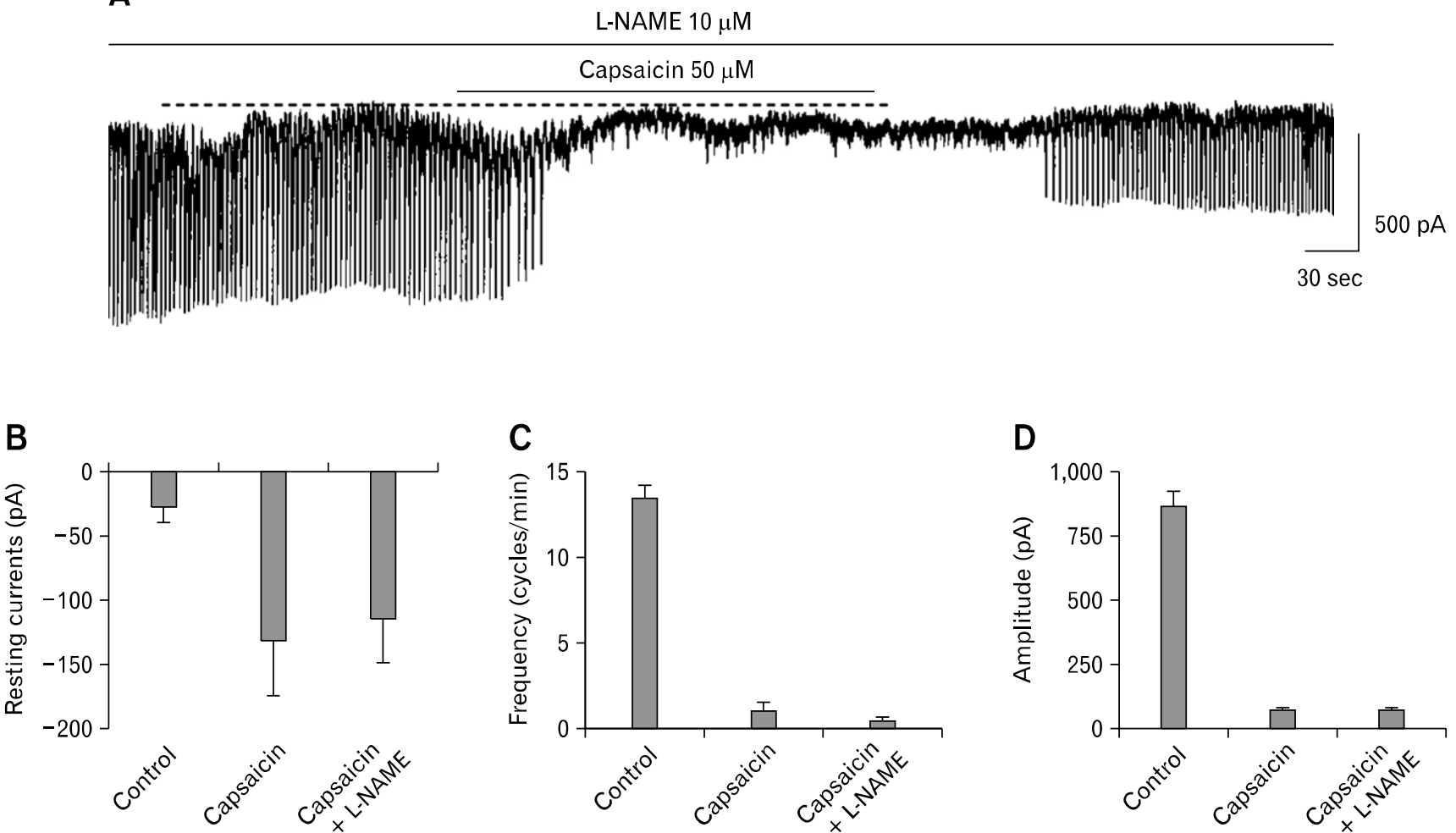

Figure 4. Effect of capsaicin in the presence of nitric oxide synthase inhibitor, L-NAME on pacemaker currents in cultured ICC. (A) The pretreatment of L-NAME $(10 \mu \mathrm{M})$ did not show any influence on normal pacemaker currents and the inhibitory effect of capsaicin $(50 \mu \mathrm{M})$ was not blocked even after the pretreatment of L-NAME in the voltage clamp mode at the holding potential of $-70 \mathrm{mV}$. The dot lines indicate the control resting current levels. There is summarized data of capsaicin's effect on resting current (B), frequency (C) and amplitude (D) respectively in the presence of L-NAME. The bars represent mean values \pm SE. 
A

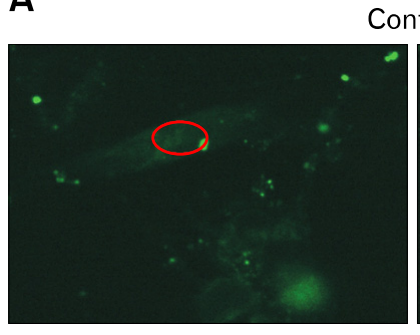

Basal 1

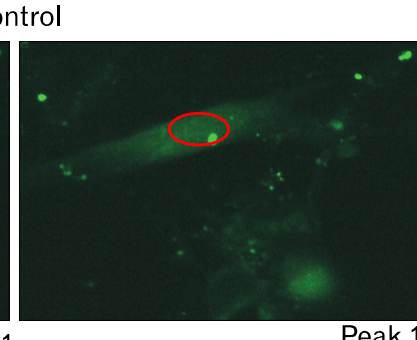

Peak

C

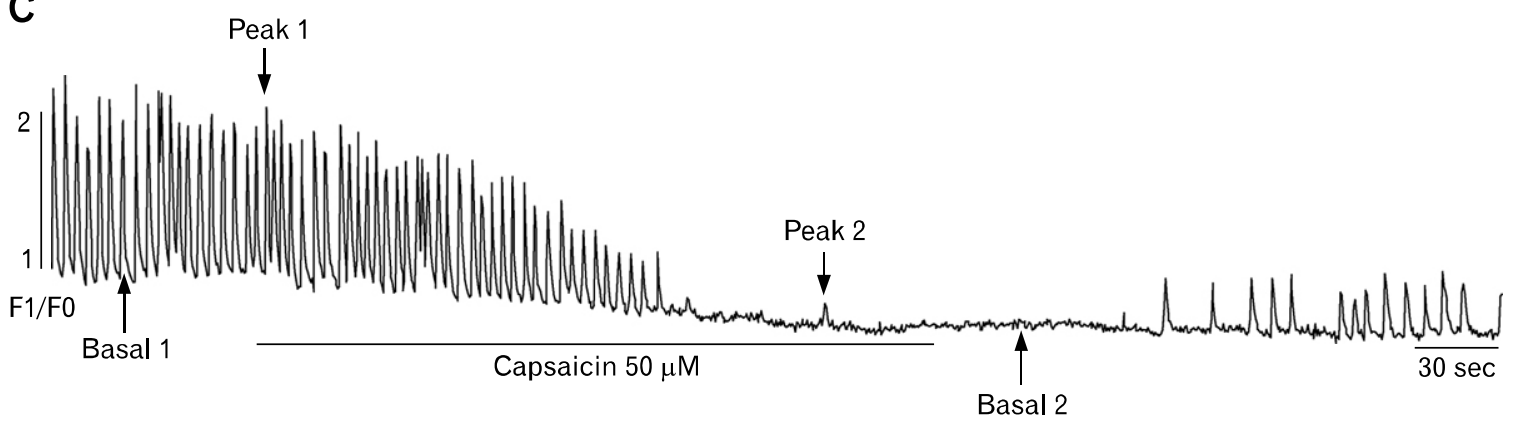

Figure 5. Effects of capsaicin on intracellular $\mathrm{Ca}^{2+}$ oscillation in cultured interstitial cells of Cajal. (A) Sequential fluorescence intensity images of fluo-4-loaded cultured ICC in normal condition. (B) Sequential fluorescence intensity images of fluo-4-loaded cultured ICC in the presence of capsaicin $(50 \mu \mathrm{M})$. The representative frames indicate in (C) basal 1, 2, peak 1, and 2. And the exposure time of each frame is $500 \mathrm{~ms}$. (C) Fluorescence intensity change plotted in (A) and (B) red marker in the absence and presence of capsaicin. The horizontal solid line scales duration of fluorescence intensity change (sec).

hibitory actions on the spontaneous pacemaker current generated by the cultured ICC.

Previous reports have shown that ICC generate spontaneous pacemaker currents that depolarize membrane, which then spread to smooth muscles via gap junctions, resulting in the depolarization of smooth muscle cell membrane. ${ }^{23}$ In our study, the ICC showed spontaneous depolarization under current clamp mode and also this activity was mirrored by spontaneous inward currents under voltage clamp mode at a holding potential -70 $\mathrm{mV}$. These results indicated that our cultured ICC were useful in investigation of the electrical rhythm and frequency regulation of pacemaker potentials and pacemaker currents in small intestine.

The TRPV1 channel is referred to as the capsaicin receptor and capsaicin stimulates the TRPV1 channels, usually followed by the stimulation of primary afferent neurons. Immunohistochemical studies have demonstrated the presence of TRPV1 channels in various layers of the GI tract. ${ }^{24-26}$ Therefore, TRPV1 has become an important target for pharmacological research in GI research and capsaicin has been used to stimulate the afferent fiber to investigate the TRPV1 effects in GI tract. To investigate
B

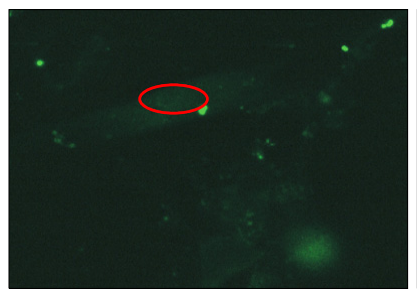

Basal 2

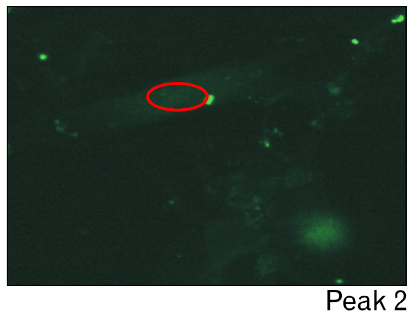


capsaicin, capsaicin in ICC can modulate TRPC4 or TRPM7 channels with other signaling pathway. To elucidate how capsaicin act on TRPC4 or TRPM7 channels in ICC, further studies should be done.

It is well known capsaicin-sensitive sensory nerves to be present in GI tract ${ }^{30}$ and capsaicin to release many substances from capsaicin-sensitive sensory nerves of various tissues. ${ }^{31,32}$ There are some reports that capsaicin induced a relaxation via nitric oxide released from the capsaicin-sensitive sensory nerves in the stomach and ileum of guinea-pig. ${ }^{6,33}$ Furthermore, it was reported that ICC had the nitric oxide synthase and nitric oxide signaling could be amplified by ICC from canine colon. ${ }^{34}$ Taken together, these results and previous reports suggest capsaicin to regulate the pacemaker activity in small intestinal ICC which might be by the release of endogenous substance. However, we were not able to see any influence on capsaicin-induced action by L-NAME, an inhibitor of nitric oxide synthase in this study which means that the effects of capsaicin on ICC are not involved in the release of nitric oxide.

Next, with regard to the regulation of non-selective cation channels by capsaicin in ICC, we examined which mechanisms are involved in the actions of capsaicin. We focused on the periodic pacemaker activity of ICC which is dependent on $\left[\mathrm{Ca}^{2+}\right]_{\mathrm{i}}$ oscillations. It is well known that the pacemaker mechanism is initiated by release of $\mathrm{Ca}^{2+}$ from the endoplasmic reticulum and is followed by reuptake of $\mathrm{Ca}^{2+}$ into the mitochondria. ${ }^{18}$ Their results suggest that $\left[\mathrm{Ca}^{2+}\right]_{i}$ plays a crucial role in pacemaking and $\mathrm{Ca}^{2+}$ imaging at the tissue level to be a useful technique to investigate slow wave propagation in GI muscle. ${ }^{35-37}$ In this study, we could see the spontaneous $\left[\mathrm{Ca}^{2+}\right]_{\mathrm{i}}$ oscillations using $\mathrm{Ca}^{2+}$ live cell imaging and $\left[\mathrm{Ca}^{2+}\right]_{i}$ oscillations was diminished by capsaicin which returned back to normal condition after the washout showing similar effect on electrophysiological studies. The actions of capsaicin on $\left[\mathrm{Ca}^{2+}\right]_{\mathrm{i}}$ oscillations in ICC are in accordance with the suggestion that $\left[\mathrm{Ca}^{2+}\right]_{\mathrm{i}}$ oscillations are important for the pacemaker activity. This means that the inhibitory action of capsaicin on pacemaker activity in ICC is closely related to the modulation of $\left[\mathrm{Ca}^{2+}\right]_{i}$.

In conclusion, the present results indicate that capsaicin attenuates the pacemaker current generated by ICC of the small intestine of mouse. These actions are carried out neither through the TRPV1 channel nor nitric oxide releasing, but the modulation of $\left[\mathrm{Ca}^{2+}\right]_{\mathrm{i}}$ by capsaicin is important for regulating the pacemaker activity in ICC. Further studies are needed to find out the exact signaling mechanism in the future.

\section{References}

1. Sindrup SH, Jensen TS. Efficacy of pharmacological treatments of neuropathic pain: an update and effect related to mechanism of drug action. Pain 1999;83:389-400.

2. Tominaga M, Tominaga T. Structure and function of TRPV1. Pflugers Arch 2005;451:143-150.

3. Buck SH, Burks TF. The neuropharmacology of capsaicin: review of some recent observations. Pharmacol Rev 1986;38:179-226.

4. Holzer P. Capsaicin: cellular targets, mechanisms of action, and selectivity for thin sensory neurons. Pharmacol Rev 1991;43:143-201.

5. Bartho L, Holzer P, Lembeck F, Szolcsanyi J. Evidence that the contractile response of the guinea-pig ileum to capsaicin is due to release of substance P. J Physiol 1982;332:157-167.

6. Bartho L, Holzer P. The inhibitory modulation of guinea-pig intestinal peristalsis caused by capsaicin involves calcitonin gene-related peptide and nitric oxide. Naunyn Schmiedebergs Arch Pharmacol 1995;353:102-109.

7. Gunthorpe MJ, Szallasi A. Peripheral TRPV1 receptors as targets for drug development: new molecules and mechanisms. Curr Pharm Des 2008;14:32-41.

8. Suri A, Szallasi A. The emerging role of TRPV1 in diabetes and obesity. Trends Pharmacol Sci 2008;29:29-36.

9. Sterner O, Szallasi A. Novel natural vanilloid receptor agonists: new therapeutic targets for drug development. Trends Pharmacol Sci 1999;20:459-465.

10. Min JK, Han KY, Kim EC, et al. Capsaicin inhibits in vitro and in vivo angiogenesis. Cancer Res 2004;64:644-651.

11. Bartho L, Benko R, Patacchini R,et al. Effects of capsaicin on visceral smooth muscle: a valuable tool for sensory neurotransmitter identification. Eur J Pharmacol 2004;500:143-157.

12. Bartho L, Benko R, Lazar Z, Illenyi L, Horvath OP. Nitric oxide is involved in the relaxant effect of capsaicin in the human sigmoid colon circular muscle. Naunyn Schmiedebergs Arch Pharmacol 2002; 366:496-500.

13. Maggi CA, Giuliani S, Santicioli P, et al. Direct evidence for the involvement of vasoactive intestinal polypeptide in the motor response of the human isolated ileum to capsaicin. Eur J Pharmacol 1990; 185:169-178.

14. Maggi CA, Theodorsson E, Santicioli P, et al. Motor response of the human isolated colon to capsaicin and its relationship to release of vasoactive intestinal polypeptide. Neuroscience 1990;39:833-841.

15. Langton P, Ward SM, Carl A, Norell MA, Sanders KM. Spontaneous electrical activity of interstitial cells of Cajal isolated from canine proximal colon. Proc Natl Acad Sci USA 1989;86: 7280-7284.

16. Ward SM, Burns AJ, Torihashi S, Sanders KM. Mutation of the proto-oncogene c-kit blocks development of interstitial cells and electrical rhythmicity in murine intestine. J Physiol 1994;480:91-97.

17. Huizinga JD, Thuneberg L, Kluppel M, Malysz J, Mikkelsen HB, Bernstein A. W/kit gene required for intestinal pacemaker activity. Nature 1995;373:347-349.

18. Sanders KM. A case for interstitial cells of Cajal as pacemakers and mediators of neurotransmission in the gastrointestinal tract. Gas- 
troenterology 1996;111:492-515.

19. Park KJ. Interstitial cells of Cajal and GI motility. Korean J Neurogastroenterol Motil 2004;10:93-99.

20. Koh SD, Sanders KM, Ward SM. Spontaneous electrical rhythmicity in cultured interstitial cells of Cajal from the murine small intestine. J Physiol 1998;513:203-213.

21. Xing J, Ma J, Zhang P, Fan X. Block effect of capsaicin on hERG potassium currents is enhanced by S6 mutation at Y652. Eur J Pharmacol 2010;630:1-9.

22. Isoda H, Han J, Tominaga M, Maekawa T. Effects of capsaicin on human intestinal cell line Caco-2. Cytotechnology 2001;36:155-161.

23. Koh SD, Kim TW, Jun JY, Glasgow NJ, Ward SM, Sanders KM. Regulaton of pacemaker currents in interstitial cells of Cajal from murine small intestine by cyclic nucleotides. J Physiol 2000;527: 149-162.

24. Horie S, Yamamoto H, Michael GJ, et al. Protective role of vanilloid receptor type 1 in $\mathrm{HCl}$-induced gastric mucosal lesions in rats. Scand J Gastroenterol 2004;39:303-312.

25. Patterson LM, Zheng H, Ward SM, Berthoud HR. Vanilloid receptor (VR1) expression in vagal afferent neurons innervating the gastrointestinal tract. Cell Tissue Res 2003;311:277-287.

26. Ward SM, Bayguinov J, Won KJ, Grundy D, Berthoud HR. Distribution of the vanilloid receptor (VR1) in the gastrointestinal tract. J Comp Neurol 2003;465:121-135.

27. Jun JY, Yang ES, Kim KH, Chnag IY. Vanilloid receptor type-1 immunoreactivities in the mouse myenteric plexus: Immunohistochemical and electrophysiological study. Korean J Phys Anthropol 2004; 17:45-53.

28. Kim BJ, So I, Kim KW. The relationship of TRP channels to the pacemaker activity of interstitial cells of Cajal in the gastrointestinal tract. J Smooth Muscle Res 2006;42:1-7.
29. Kuriyama H, Kitamura K, Itoh T, Inoue R. Physiological features of visceral smooth muscle cells, with special reference to receptors and ion channels. Physiol Rev 1998;78:811-920.

30. Tepperman BL, Whittle BJ. Endogenous nitric oxide and sensory neuropeptides interact in the modulation of the rat gastric microcirculation. Br J Pharmacol 1992;105:171-175.

31. Franco-Cereceda A, Henke H, Lundbeg JM, Petermann JB, Hokfelt T, Fischer JA. Calcitonin gene-related peptide (CGRP) in capsaicin-sensitive substance P-immunoreactive sensory neurons in animals and man: distribution and release by capsaicin. Peptides 1987;8:399-410.

32. Gibbins IL, Furness JB, Costa M. Pathway-specific patterns of the co-existence of substance $\mathrm{P}$, calcitonin gene-related peptide, cholecystokinin and dynorphin in neurons of the dorsal root ganglia of the guinea-pig. Cell Tissue Res 1987;248:417-437.

33. Uno H, Arakawa T, Fukuda T, Higuchi K, Kobayashi K. Involvement of capsaicin-sensitive sensory nerves in gastric adaptive relaxation in isolated guinea-pig stomachs. Digestion 1997;58: 232-239.

34. Publicover NG, Hammond EM, Sanders KM. Amplification of nitric oxide signaling by interstitial cells isolated from canine colon. Proc Natl Acad Sci 1993;90:2087-2091.

35. Suzuki H, Takano H, Yamamoto Y, et al. Properties of gastric smooth muscles obtained from mice which lack inositol triphosphate receptor. J Physiol 2000;525:105-111.

36. Ward SM, Ordog T, Koh SD, et al. Pacemaking in interstitial cells of Cajal depends upon calcium handling by endoplasmic reticulum and mitochondria. J Physiol 2000;525:355-361.

37. Torihashi S, Fujimoto T, Trost C, Nakayama S. Calcium oscillation linked to pacemaking of interstitial cells of Cajal: requirement of calcium influx and localization of TRP4 in caveolae. J Biol Chem 2002;277:19191-19197. 